\title{
Article \\ Graphene Oxide-Silver Nanoparticle Nanocomposites Induce Oxidative Stress and Aberrant Methylation in Caprine Fetal Fibroblast Cells
}

\author{
Yu-Guo Yuan ${ }^{1,2, *}$, He-Qing Cai ${ }^{1}$, Jia-Lin Wang ${ }^{1}$, Ayman Mesalam ${ }^{3} \mathbb{D}$, Abu Musa Md Talimur Reza ${ }^{4} \mathbb{D}$, Ling Li $^{1}$, \\ Li Chen ${ }^{1}$ and Chen Qian ${ }^{1}$
}

check for

updates

Citation: Yuan, Y.-G.; Cai, H.-Q.; Wang, J.-L.; Mesalam, A.; Md Talimur Reza, A.M.; Li, L.; Chen, L.; Qian, C. Graphene Oxide-Silver Nanoparticle Nanocomposites Induce Oxidative Stress and Aberrant Methylation in Caprine Fetal Fibroblast Cells. Cells 2021, 10, 682. https://doi.org/ $10.3390 /$ cells 10030682

Academic Editor:

Fernanda Amicarelli

Received: 8 February 2021

Accepted: 16 March 2021

Published: 19 March 2021

Publisher's Note: MDPI stays neutral with regard to jurisdictional claims in published maps and institutional affiliations.

Copyright: (c) 2021 by the authors. Licensee MDPI, Basel, Switzerland. This article is an open access article distributed under the terms and conditions of the Creative Commons Attribution (CC BY) license (https:/ / creativecommons.org/licenses/by/ $4.0 /)$.
1 College of Veterinary Medicine/Joint International Research Laboratory of Agriculture and Agri-Product Safety, the Ministry of Education of China, Yangzhou University, Yangzhou 225009, China;

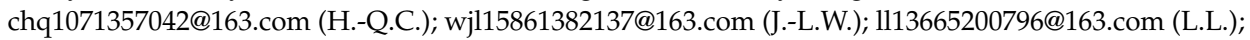
007238@yzu.edu.cn (L.C.); 13905271422@163.com (C.Q.)

2 Jiangsu Co-Innovation Center for Prevention and Control of Important Animal Infectious Diseases and Zoonoses/Jiangsu Key Laboratory of Zoonosis, Yangzhou 225009, China

3 Department of Theriogenology, Faculty of Veterinary Medicine, Zagazig University, Zagazig 44519, Egypt; aymanmesalam@gmail.com

4 Institute of Biochemistry and Biophysics, Polish Academy of Sciences, Pawińskiego 5a, 02-106 Warsaw, Poland; talimurku@gmail.com

* Correspondence: ygyuan@yzu.edu.cn; Tel.: +86-514-87979228
Abstract: Graphene oxide-silver nanoparticle (GO-AgNPs) nanocomposites have drawn much attention for their potential in biomedical uses. However, the potential toxicity of GO-AgNPs in animals and humans remains unknown, particularly in the developing fetus. Here, we reported the GO-AgNP-mediated cytotoxicity and epigenetic alteration status in caprine fetal fibroblast cells (CFFCs). In brief, the proliferation and apoptosis rate of GO-AgNP-treated CFFCs (4 and $8 \mu \mathrm{g} / \mathrm{mL}$ of GO-AgNPs) were measured using the cell-counting kit (CCK-8) assay and the annexin $\mathrm{V} /$ propidium iodide (PI) assay, respectively. In addition, the oxidative stress induced by GOAgNPs and detailed mechanisms were studied by evaluating the generation of reactive oxygen species (ROS), superoxide dismutase (SOD), lactate dehydrogenase (LDH), malondialdehyde (MDA), and caspase- 3 and abnormal methylation. The expression of pro- and anti-apoptotic genes and DNA methyltransferases was measured using reverse transcription followed by RT-qPCR. Our data indicated that GO-AgNPs cause cytotoxicity in a dose-dependent manner. GO-AgNPs induced significant cytotoxicity by the loss of cell viability, production of ROS, increasing leakage of LDH and level of MDA, increasing expression of pro-apoptotic genes, and decreasing expression of anti-apoptotic genes. GO-AgNPs incited DNA hypomethylation and the decreased expression of DNMT3A. Taken together, this study showed that GO-AgNPs increase the generation of ROS and cause apoptosis and DNA hypomethylation in CFFCs. Therefore, the potential applications of GO-AgNPs in biomedicine should be re-evaluated.

Keywords: graphene oxide; silver nanoparticles; caprine fetal fibroblast cells (CFFCs); reactive oxygen species (ROS); epigenetic

\section{Introduction}

Nanotoxicity involves the understanding of the adverse biological effects of nanoparticles using both in vitro and in vivo model systems such as cells, tissues, organs, and organisms [1]. In vitro assays are the first approach to determining the cytotoxicity of nanomaterials. Several studies have been dedicated to examining the effects of graphene and graphene-related nanomaterials in various cell culture systems, including HeLa, MCF-7, SKBR3, NIH3T3, epithelial lung carcinoma, primary mouse embryonic fibroblast, human 
breast cancer, and ovarian cancer cells [2-5]. It has been shown that graphene and graphenerelated nanomaterials lead to a pro-inflammatory response in the liver and kidney [6,7], cause genotoxicity and DNA damage [8], and adversely impact the function of the lungs, heart, intestines, and spleen [9-11]. In addition, depending on the size, oxidative status, and concentration of nanoparticles, and the used experimental model, graphene, graphene oxide (GO), and reduced GO have shown different levels of cytotoxicity [12,13]. Previous research showed the involvement of different nanocomposites in the abnormal methylation of mammalian DNA [14]. However, the role of the graphene-derived nanocomposite in the aberrant methylation status of DNA in livestock species has not been reported yet.

Silver nanoparticles (AgNPs) are one of the most frequently used nanoparticles in a variety of biomedical applications [15]. Recently, investigating the potential of using hybrid nanomaterials such as graphene oxide-silver nanoparticle (GO-AgNPs) nanocomposites is becoming popular in biomedical research because of their unique functions and properties [16]. For example, attaching AgNPs on to the surface of GO sheets can prevent the AgNPs from aggregating, allowing for a more controlled release of AgNPs+ ions, and lead to an increase in antibacterial and anticancer activity $[17,18]$. The commercial use of this kind of nanocomposite might cause a slow but chronic exposure to human, animal, and other forms of environmental elements. For instance, exposure to AgNPs causes their accumulation in cells and animal tissues (such as the heart, kidney, and other organs) [19-21], which may interfere with transport pathways, nuclear signaling, endocytosis, reproductive behavior, and general defenses by alteration of gene expression [22,23]. Therefore, the potential toxicity of our synthesized GO-AgNPs needs to be explored in detail.

Our previous study aimed at the use of nanomaterials in veterinary treatment showed that $1 \mu \mathrm{g} / \mathrm{mL}$ of AgNPs is effective against multidrug-resistant (MDR) bacteria in dairy goats [24]. However, AgNPs could be translocated to the bloodstream and transported throughout the organs of the body, including reproductive organs, which might cause disruption of reproductive system development, birth weight reduction, and other fetalmaternal disorders [25]. Thus, it becomes essential to investigate the potential cytotoxic and genotoxic effects of our newly synthesized GO-AgNP nanocomposite before its application in the treatment of bovine and caprine mastitis. The current research was undertaken to investigate the cytotoxic and genotoxic effects of GO-AgNPs in caprine fetal fibroblast cells (CFFCs), which is a suitable in vitro model for studying the nanomaterial-mediated toxicity to the fetus. The results showed that GO-AgNPs cause aberrant methylation of CFFCs. To the best of our knowledge, this is the first evidence showing that GO-AgNPs could impair the epigenetic status of fetal fibroblasts in livestock species.

\section{Materials and Methods}

\subsection{Chemicals}

All chemicals and reagents were purchased from Sigma-Aldrich (St. Louis, MO, USA) unless otherwise stated.

\subsection{Synthesis and Characterization of GO-AgNPs}

A GO-AgNP nanocomposite was synthesized using the biomolecule quercetin, as described previously [26], and then lyophilized and kept in a lab at $4{ }^{\circ} \mathrm{C}$ until use. Briefly, $50 \mathrm{mg}$ of GO was dispersed in $30 \mathrm{~mL}$ of water and sonicated for $60 \mathrm{~min}$. Then, $1 \mathrm{mM} \mathrm{AgNO}$ was dissolved in $15 \mathrm{~mL}$ of water in a $500 \mathrm{~mL}$ round-bottom flask. Next, $30 \mathrm{~mL}$ of the GO dispersion was added, followed by addition of $5 \mathrm{~mL}$ of aqueous $1 \mathrm{mM}$ quercetin, and then stirred at $60^{\circ} \mathrm{C}$ for $12 \mathrm{~h}$. The resultant mixture was washed and centrifuged three times with water. Physicochemical characterization of GO-AgNPs was checked by Fourier-transform infrared spectroscopy and X-ray diffraction. The size and shape were observed under a transmission electron microscope (TEM; HT7800, Hitachi High-Technologies Corporation, Tokyo, Japan). 


\subsection{Cell Culture}

CFFCs were isolated from 70-day-old fetuses that were recovered surgically from a Boer goat obtained from the Yangzhou University farm, as previously described [27]. Briefly, pregnant goats were anesthetized using an intramuscular injection of serazine hydrochloride $(0.02 \mathrm{~mL} / \mathrm{kg}$ body weight), and fetuses were collected. After removal of the head and internal organs, the remaining tissues of fetuses were dissociated into small pieces using scissors and digested with $0.25 \%$ trypsin (Thermo Fisher Scientific, Waltham, MA, USA). Then, cells were washed three times, centrifuged to recover them, and cultured in Dulbecco's Modified Eagle's Medium/F12 (DMEM/F12; Thermo Fisher Scientific, Waltham, MA, USA) supplemented with $10 \%$ fetal bovine serum (FBS; Hangzhou Sijiqing Hangzhou, China) at $37^{\circ} \mathrm{C}$ in a humidified atmosphere of $5 \% \mathrm{CO}_{2}$. The cells were used at passages 3-10.

\subsection{Cell Viability Assay}

The cell viability was assessed by using an in vitro cell-counting kit (CCK-8; Rockville, MD, USA) assay, as described previously [28]. CFFCs were seeded in a 96-well or 6-well plate and cultured for $24 \mathrm{~h}$ to allow adherence and stabilization. GO-AgNPs were sonicated for $20 \mathrm{~min}$ before use. Then, the GO-AgNP suspension was dispersed in DMEM/F12 at different concentrations $(1,4,8,12$, and $16 \mu \mathrm{g} / \mathrm{mL})$ for $24 \mathrm{~h}$ at $37^{\circ} \mathrm{C}$. After culture, $10 \mu \mathrm{L}$ of CCK- 8 was added to each well and incubated for $30 \mathrm{~min}$ at $37^{\circ} \mathrm{C}$ in the dark. The absorbance at $450 \mathrm{~nm}$ was measured using a microplate reader (BioTek Synergy 2, Winooski, VT, USA). After calculating the LC50 value from the resultant cell viability data, 4 and $8 \mu \mathrm{g} / \mathrm{mL}$ concentrations were selected for further experiments. This study was designed and blinded throughout all stages of the methodological process.

\subsection{Cell Morphology}

CFFCs were seeded in a 24-well plate for $24 \mathrm{~h}$ and then treated with 0,4 , and $8 \mu \mathrm{g} / \mathrm{mL}$ of GO-AgNPs for $24 \mathrm{~h}$. Cell morphology was observed using an Olympus BX-UCB microscope (Tokyo, Japan).

\subsection{Annexin V-FITC/PI Staining Assay}

CFFCs were seeded in a $75 \mathrm{~mm}$ culture plate and treated with different concentrations of GO-AgNPs $(0,4$, and $8 \mu \mathrm{g} / \mathrm{mL})$ for $24 \mathrm{~h}$. Cell apoptosis of CFFCs was detected by the annexin V-FITC and propidium iodide (PI) staining assay according to the manufacturer's instructions (Bipec Biopharma Corporation, Warminster, PA, USA). The cells were harvested, centrifuged for $5 \mathrm{~min}$, rinsed with phosphate-buffered saline (PBS) twice, resuspended in $500 \mu \mathrm{L}$ of binding buffer containing $5 \mu \mathrm{L}$ of PI and $5 \mu \mathrm{L}$ of annexin V-FITC, and then incubated for $15 \mathrm{~min}$ at room temperature in the dark. The cell suspension was analyzed by flow cytometry to analyze the apoptotic rate.

\subsection{Measurement of ROS Production}

Dichlorodihydrofluorescein diacetate (DCFH-DA) was used to detect intracellular ROS induced by 0,4 , and $8 \mu \mathrm{g} / \mathrm{mL}$ of GO-AgNPs, as described earlier [28]. In brief, CFFCs were incubated in $10 \mu \mathrm{M}$ DCFH-DA for $30 \mathrm{~min}$ at $37^{\circ} \mathrm{C}$. The cells were rinsed with PBS twice, and then the intracellular accumulation of ROS was measured by flow cytometry (Beckman-Coulter, Irving, TX, USA).

\subsection{Measurement of Total Superoxide Dismutase (SOD) Enzyme Activity}

The SOD assay kit (Beijing Solarbio Science \& Technology, Beijing, China) was used to detect the activity of SOD in the CFFCs treated with 0,4 , and $8 \mu \mathrm{g} / \mathrm{mL}$ of GO-AgNPs for $24 \mathrm{~h}$ [28]. In brief, after treatment with GO-AgNPs, the cells were washed with PBS twice and lysed with lysis buffer on ice. The lysates were then centrifuged for $15 \mathrm{~min}$. Then, the supernatant was analyzed with a UV-VIS spectrophotometer (Nanodrop, Thermo, Waltham, MA, USA) at $550 \mathrm{~nm}$. 


\subsection{Measurement of Malondialdehyde (MDA) Production}

MDA, a convenient index for detecting the extent of lipid peroxidation reactions, was measured using the MDA assay kit (Beijing Solarbio Science \& Technology, Beijing, China) according to the manufacturer's instructions [29]. Cells were plated in 6-well plates at a density of $1.0 \times 10^{5}$ cells per well and cultured for $24 \mathrm{~h}$ to allow adherence, before exposure to 0,4 , and $8 \mu \mathrm{g} / \mathrm{mL}$ of GO-AgNPs for $24 \mathrm{~h}$. Then, the cells were washed with PBS twice and MDA activities were quantitated by reading optical densities at $532 \mathrm{~nm}$ using a Synergy 2 multi-mode microplate reader (BioTek, USA).

\subsection{Measurement of Lactate Dehydrogenase (LDH) Production}

CFFCs were seeded in a 24-well culture plate and treated with 0,4 , and $8 \mu \mathrm{g} / \mathrm{mL}$ of GO-AgNPs for $24 \mathrm{~h}$. LDH levels of cells in the culture medium were quantified using the LDH-cytotoxicity assay kit (Beijing Solarbio Science \& Technology, Beijing, China) [29]. LDH activities were quantitated by reading optical densities at $490 \mathrm{~nm}$ using a Synergy 2 multi-mode microplate reader (BioTek, USA).

\subsection{Measurement of Caspase-3 Activity}

Caspase-3 activity was measured using a caspase-3 activity kit (Beijing Solarbio Science \& Technology, Beijing, China) according to manufacturer's instructions. Briefly, CFFCs were seeded in a 24-well culture plate and treated with 0,4 , and $8 \mu \mathrm{g} / \mathrm{mL}$ of GO-AgNPs for $24 \mathrm{~h}$. Then, the cells were washed twice in PBS, lysed using lysis buffer, and centrifuged at $16,000 \times g$ at $4{ }^{\circ} \mathrm{C}$ for $10 \mathrm{~min}$, and the supernatant was incubated with $10 \mu \mathrm{L}$ of caspase-3 substrate for $7 \mathrm{~h}$ at $37^{\circ} \mathrm{C}$. Substrate cleavage was measured at $405 \mathrm{~nm}$ using a Synergy 2 multi-mode microplate reader (BioTek, USA).

\subsection{Determination of Global 5- $m \mathrm{C}$}

Genomic DNA from cultured cells was purified with the DNeasy blood and tissue kit (Qiagen, Inc, Hilden, Germany). Global DNA methylation was determined according to the Methyl Flash Methylated DNA Quantification Kit (Colorimetric; Epigentek Group Inc., New York, NY, USA). Briefly, the percentage of 5-mC in $100 \mathrm{ng}$ of DNA was proportional to the OD intensity in an ELISA plate reader at $450 \mathrm{~nm}$. DNA methylation was calculated using the formula $[(($ Sample OD $-\mathrm{M} 3 \mathrm{OD}) / \mathrm{S}) /((\mathrm{M} 4 \mathrm{OD}-\mathrm{M} 3 \mathrm{OD}) \times 2) / \mathrm{P}] \times 100$, where $\mathrm{OD}$ is the optical density; M3 is the negative control, an unmethylated polynucleotide containing $50 \%$ of cytosine; $\mathrm{S}$ is the amount of input sample DNA in nanograms; $\mathrm{M} 4$ is the positive control, a methylated polynucleotide containing $50 \%$ of 5 -methylcystosine; and $\mathrm{P}$ is the amount of input positive control in nanograms. The relative amount of methylated DNA was expressed as a percentage of total DNA.

\subsection{Quantitative Reverse Transcription PCR (RT-qPCR) Analysis}

Total RNA was extracted from CFFCs using an RNA Isolation Kit (Thermo Scientific, Waltham, MA, USA) according to the manufacturer's instructions. RNA samples were stored at $-80^{\circ} \mathrm{C}$ until use. The mRNA samples were reverse-transcribed into first-strand cDNA using the iScript cDNA Synthesis Kit (Bio-Rad Laboratories, Hercules, CA, USA) according to the manufacturer's instructions. Quantitative analysis of the cDNA samples was performed using a CFX96 instrument (Bio-Rad Laboratories), using SYBR Green (Vazyme). Primers were designed based on the mRNA sequences of selected genes available in GenBank (Table 1). The PCR cycle was as follows: initial denaturation at $95^{\circ} \mathrm{C}$ for $30 \mathrm{~s}$, followed by 41 cycles of denaturation at $95^{\circ} \mathrm{C}$ for $15 \mathrm{~s}$, annealing at $60{ }^{\circ} \mathrm{C}$ for $15 \mathrm{~s}$, and extension at $72{ }^{\circ} \mathrm{C}$ for $30 \mathrm{~s}$. RT-qPCR was performed independently four times. The target genes were quantified by the delta-delta $\mathrm{Ct}$ method using CFX manager V1.1 software (Bio-Rad Laboratories). Normalization was performed using $\beta$-actin as the reference gene. 
Table 1. Primers used for quantitative reverse transcription PCR analysis.

\begin{tabular}{|c|c|c|}
\hline Gene & Primer sequence $\left(5^{\prime}-3^{\prime}\right)$ & Product Size $(b p)$ \\
\hline caspase-3 & $\begin{array}{l}\text { F: CCATGGTGAAGAAGGAATCATTT } \\
\text { R: TCCCCTCTGAAGAAACTTGCTAA }\end{array}$ & 78 \\
\hline$B A X$ & $\begin{array}{l}\text { F: GCATCCACCAAGAAGCTGAG } \\
\text { R: CCGCCACTCGGAAAAAGAC }\end{array}$ & 120 \\
\hline Smac & $\begin{array}{l}\text { F: TGTTCCAGTCGTGGCTAACTT } \\
\text { R: AAAGACACAGCCCTCCTCATT }\end{array}$ & 171 \\
\hline$B C L 2$ & $\begin{array}{l}\text { F: ATGTGTGTGGAGAGCGTCA } \\
\text { R: AGAGACAGCCAGGAGAAATC }\end{array}$ & 113 \\
\hline Hsp 70 & $\begin{array}{l}\text { F: TCAGGACTCAATCTGCATCG } \\
\text { R: ATCCGCATTTCTGGTTATCA }\end{array}$ & 210 \\
\hline DNMT3A & $\begin{array}{l}\text { F: CTTGGAGAAGCGGAGTGAGC } \\
\text { R: GTGCAGCAGCCATTCTCTACAG }\end{array}$ & 138 \\
\hline DNMT3B & $\begin{array}{c}\text { F: AGCCCCTACCTCACCATC } \\
\text { R: CTGATACTCGGTGCTGTCTGC }\end{array}$ & 156 \\
\hline DNMT1 & $\begin{array}{c}\text { F: GAGGAGGCTGCCAAGGACT } \\
\text { R: CAAACACCGCATACGACACAC }\end{array}$ & 134 \\
\hline$\beta$-actin & $\begin{array}{l}\text { F: TCACGGAGCGTGGCTACAG } \\
\text { R: CCTTGATGTCACGGACGATTT }\end{array}$ & 127 \\
\hline
\end{tabular}

Abbreviations: $\mathrm{F}$, forward; $\mathrm{R}$, reverse.

\subsection{Statistical Analysis}

The assessors were blinded to any stage of the methodological process. All results were expressed as the mean \pm SD and analyzed using Origin 8.0 and SPSS 18.0 (IBM Corp., Armonk, NY, USA). The statistical significance of the changes between tested groups and the control group was analyzed by one-way ANOVA followed by Dunnett's multiple comparison. The level of statistical significance was set at $p<0.05$. All experiments were performed at least three times.

\section{Results}

\subsection{Characterization of GO-AgNPs}

TEM analysis was conducted to confirm the structural and surface morphology of the GO-AgNP nanocomposite. The size distribution of the AgNPs was about $20 \mathrm{~nm}$, as shown in the image of TEM (Figure 1). GO-AgNPs images clearly showed transparent, single-layer sheets containing flake-like wrinkles in which AgNPs were homogeneously arranged on the micron scale of the GO sheets, which presented no evidence of agglomeration.

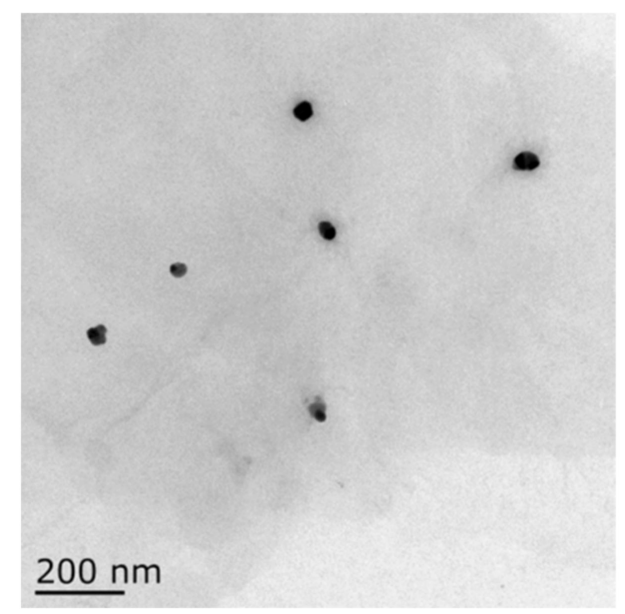

Figure 1. Size determination analysis of graphene oxide-silver nanoparticle (GO-AgNP) nanocomposites by transmission electron microscopy (TEM). The TEM image showed that the size of GO-AgNPs was about $20 \mathrm{~nm}$. 


\subsection{Effect of GO-AgNPs on Caprine Fetal Fibroblast Cell (CFFC) Viability}

For assessment of the potential cytotoxic effect of GO-AgNPs on CFFCs, cell viability following GO-AgNPs treatment was determined using the CCK-8 assay. As shown in Figure 2, there were no significant differences in cell viability between control cells and those exposed to $1 \mu \mathrm{g} / \mathrm{mL}$ of GO-AgNPs for $24 \mathrm{~h}$; however, the viability of cells was significantly reduced when the concentration increased $(4,8,12$, and $16 \mu \mathrm{g} / \mathrm{mL})$, suggesting that GO-AgNPs induce toxicity in CFFCs in a dose-dependent manner.

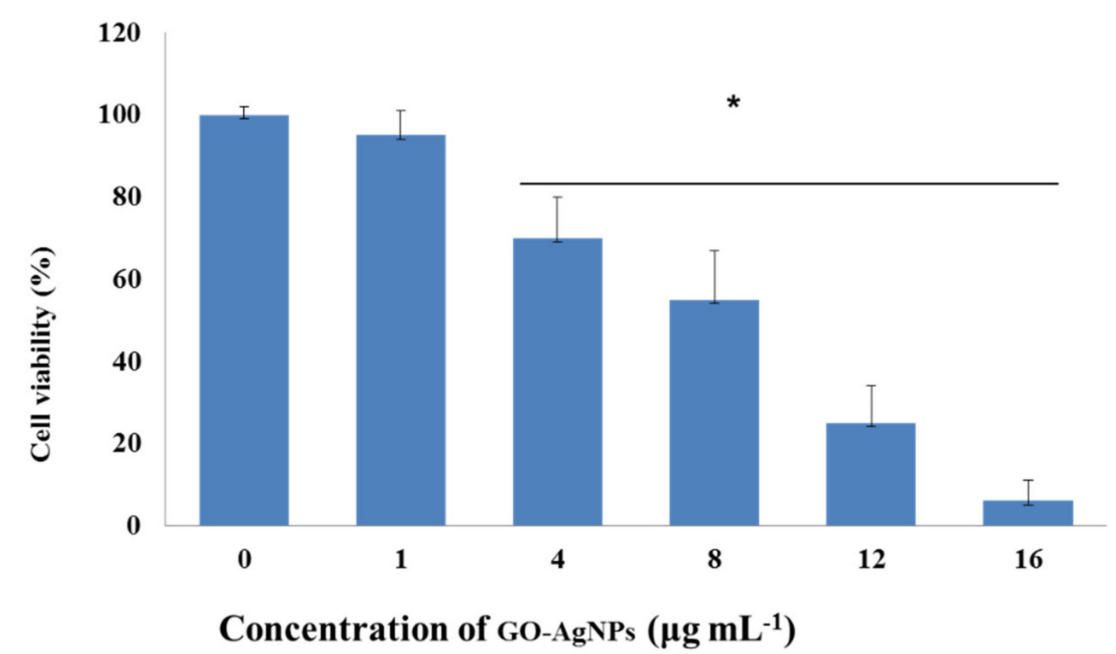

Figure 2. Effects of GO-AgNPs on the proliferation of caprine fetal fibroblast cells (CFFCs). CFFCs were exposed to $0,1,4,8,12$, and $16 \mu \mathrm{g} / \mathrm{mL}$ of GO-AgNPs for $24 \mathrm{~h}$. The percentage of cell viability was then calculated relative to the control group $(0 \mu \mathrm{g} / \mathrm{mL})$. Values are presented as the mean $\pm \mathrm{SD}$ of four independent experiments $\left({ }^{*} p<0.05\right)$.

\subsection{Effect of GO-AgNPs on Cell Morphology}

The morphologies of CFFCs after exposure to GO-AgNPs for $24 \mathrm{~h}$ are shown in Figure 3. Cell morphology of the control group was uniform with spindle-shaped cells. CFFCs that had been exposed to 4 and $8 \mu \mathrm{g} / \mathrm{mL}$ of GO-AgNPs exhibited marked morphological changes and showed cell membrane breakage, with obvious reduction in the number of cells in the group exposed to $8 \mu \mathrm{g} / \mathrm{mL}$ of GO-AgNPs.

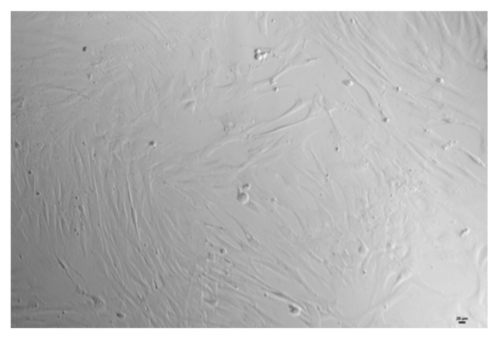

Control

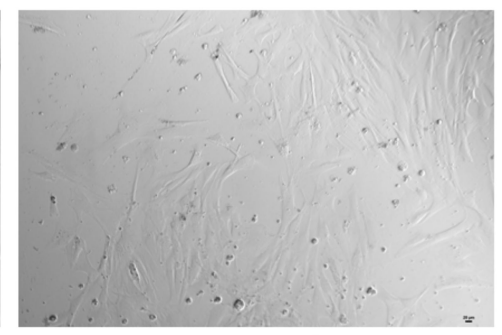

$4 \mu \mathrm{g} \mathrm{mL}^{-1}$

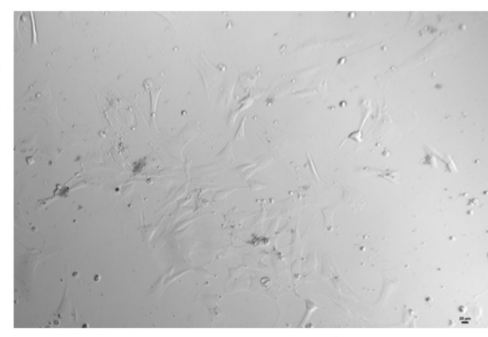

$8 \mu \mathrm{g} \mathrm{mL}-1$

Figure 3. Cell morphology following treatment with GO-AgNPs. Caprine fetal fibroblast cells (CFFCs) were treated with 0 , 4 , and $8 \mu \mathrm{g} / \mathrm{mL}$ of GO-AgNPs for $24 \mathrm{~h}$ and then visualized under a phase-contrast microscope (magnification, $100 \times$ ). Scale bar $=20 \mu \mathrm{m}$.

\subsection{Effect of GO-AgNPs on Reactive Oxygen Species (ROS) Production}

To study whether GO-AgNPs induce an oxidative impact involving apoptosis, the intracellular ROS level in CFFCs was analyzed. As shown in Figure 4, the level of intracellular ROS in CFFCs significantly increased $(p<0.05)$ when the cells were treated with 4 and $8 \mu \mathrm{g} / \mathrm{mL}$ of GO-AgNPs for $24 \mathrm{~h}$ compared to the control group. 
A
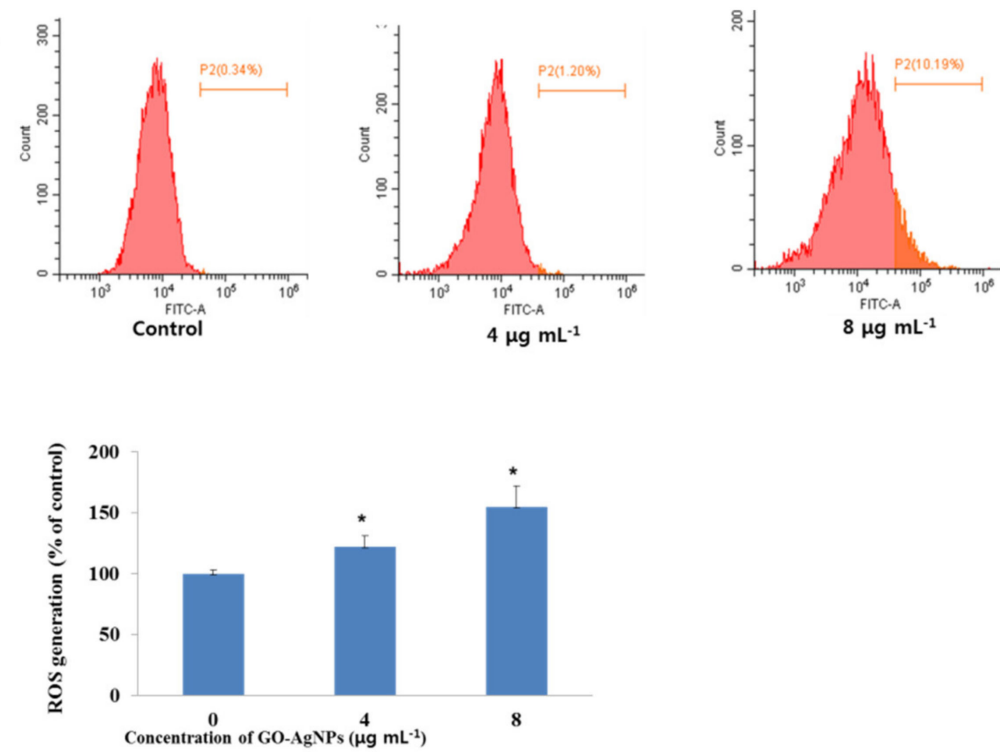

Figure 4. Total reactive oxygen species (ROS) generation in GO-AgNP-treated cells. Caprine fetal fibroblast cells (CFFCs) were treated with 0,4 , and $8 \mu \mathrm{g} / \mathrm{mL}$ of GO-AgNPs for $24 \mathrm{~h}$ and analyzed by FACS (A). The percentage of ROS generation relative to the untreated control group $(0 \mu \mathrm{g} / \mathrm{mL})(\mathbf{B})$. Values are presented as the mean $\pm \mathrm{SD}$ of four independent experiments $\left({ }^{*} p<0.05\right)$.

\subsection{Effects of GO-AgNPs on Apoptosis}

The effect of GO-AgNPs on cell apoptosis was tested. An annexin V/PI apoptosis kit was used to quantify, by flow cytometry, the percentage of CFFCs undergoing apoptosis and dying. The results suggested that GO-AgNPs induce significant apoptosis and cell death in CFFCs (Figure 5).

A

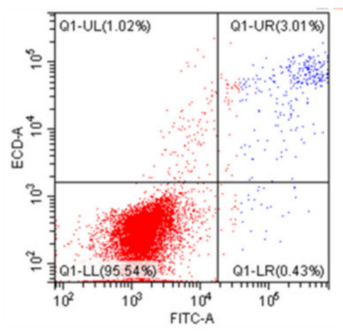

B

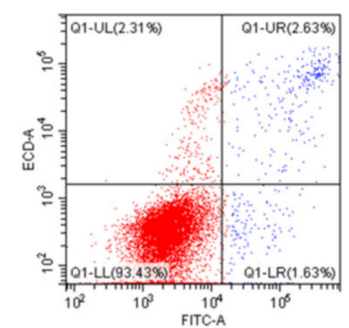

\section{C}

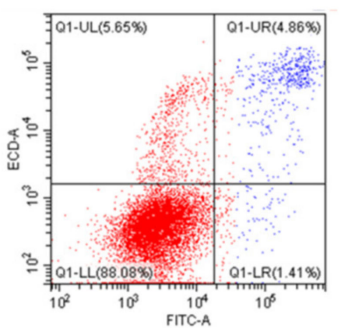

D

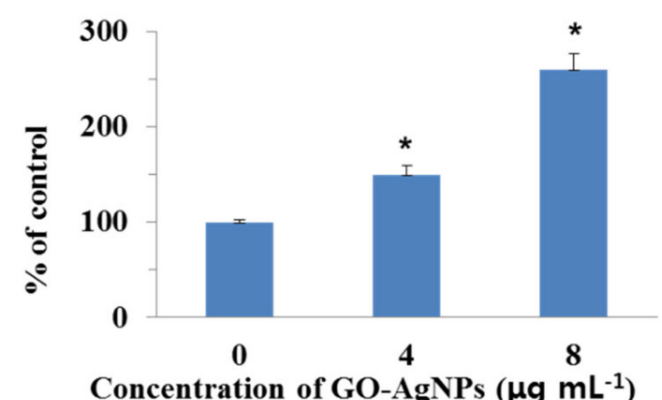

Figure 5. Evaluation of GO-AgNP-induced apoptotic cell death with the annexin V-FITC/propidium iodide (PI) staining assay. Caprine fetal fibroblast cells (CFFCs) were treated with 0 (A), 4 (B), and $8 \mu \mathrm{g} / \mathrm{mL}$ (C) of GO-AgNPs for $24 \mathrm{~h}$, and FACS was carried out for detection of fractions of early apoptotic, late apoptotic, and necrotic CFFCs. The corresponding linear diagram of flow cytometry is shown in (D). Values are presented as the mean $\pm \mathrm{SD}$ of five independent experiments $\left({ }^{*} p<0.05\right)$. 


\subsection{Effects of GO-AgNPs on SOD Production}

Effects of GO-AgNPs on the production of the anti-oxidant indicator SOD in CFFCs were determined with an SOD assay kit. As shown in Figure 6, the SOD activity decreased significantly $(p<0.05)$ in CFFCs treated with $4 \mu \mathrm{g} / \mathrm{mL}$ of GO-AgNPs for $24 \mathrm{~h}$ compared to the control group. Furthermore, CFFCs treated with $8 \mu \mathrm{g} / \mathrm{mL}$ of GO-AgNPs significantly decreased $(p<0.01)$ SOD activity compared to untreated CFFCs.

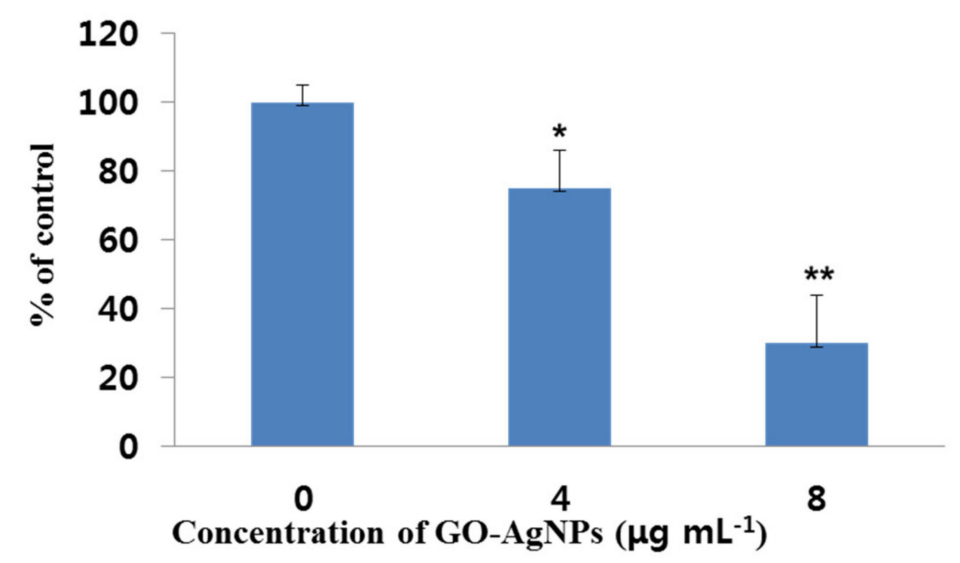

Figure 6. Measurement of superoxide dismutase (SOD) production in GO-AgNP-treated cells. Caprine fetal fibroblast cells (CFFCs) were treated with 0,4 , and $8 \mu \mathrm{g} / \mathrm{mL}$ of GO-AgNPs for $24 \mathrm{~h}$. The percentage of SOD relative to the control group $(0 \mu \mathrm{g} / \mathrm{mL})$ was determined. Values are presented as the mean $\pm \mathrm{SD}$ of four independent experiments $\left({ }^{*} p<0.05 ;{ }^{* *} p<0.01\right)$.

\subsection{Effects of GO-AgNPs on MDA Production}

The production of MDA in CFFCs was determined using the MDA assay kit after treatment with 0,4 , and $8 \mu \mathrm{g} / \mathrm{mL}$ of GO-AgNPs for $24 \mathrm{~h}$. The results showed that the levels of the oxidative damage indicator MDA increased significantly $(p<0.05)$ in the 4 and $8 \mu \mathrm{g} / \mathrm{mL}$ groups compared to the control group (Figure 7).

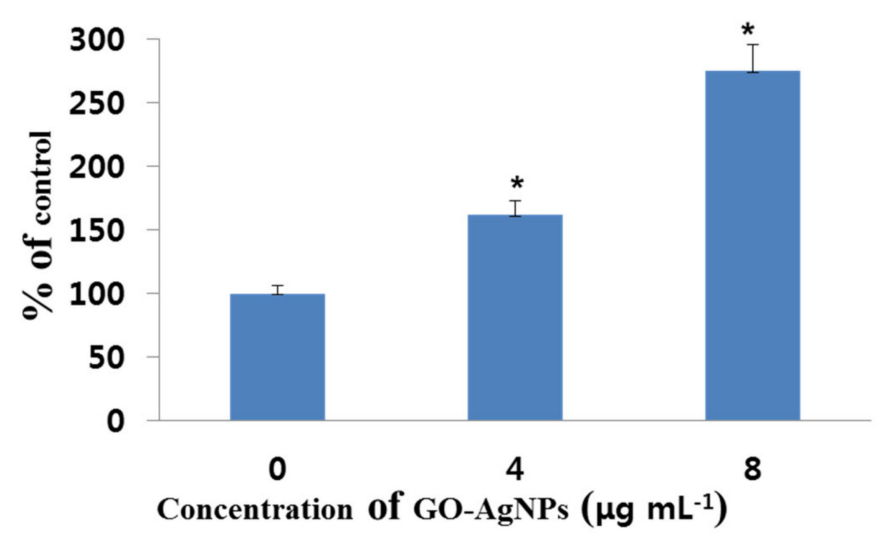

Figure 7. Measurement of malondialdehyde (MDA) production in GO-AgNP-treated cells. Caprine fetal fibroblast cells (CFFCs) were treated with 0,4 , and $8 \mu \mathrm{g} / \mathrm{mL}$ of GO-AgNPs for $24 \mathrm{~h}$. The percentage of MDA relative to the control group $(0 \mu \mathrm{g} / \mathrm{mL})$ was determined. Values are presented as the mean $\pm \mathrm{SD}$ of four independent experiments $\left({ }^{*} p<0.05\right)$.

\subsection{Effects of GO-AgNPs on $L D H$}

CFFCs were treated with 0,4 , and $8 \mu \mathrm{g} / \mathrm{mL}$ of GO-AgNPs for $24 \mathrm{~h}$, and the level of leakage of LDH was measured. The results indicated that GO-AgNPs significantly increased the leakage level of LDH in CFFCs compared to the control group (Figure 8; $p<0.05)$. 


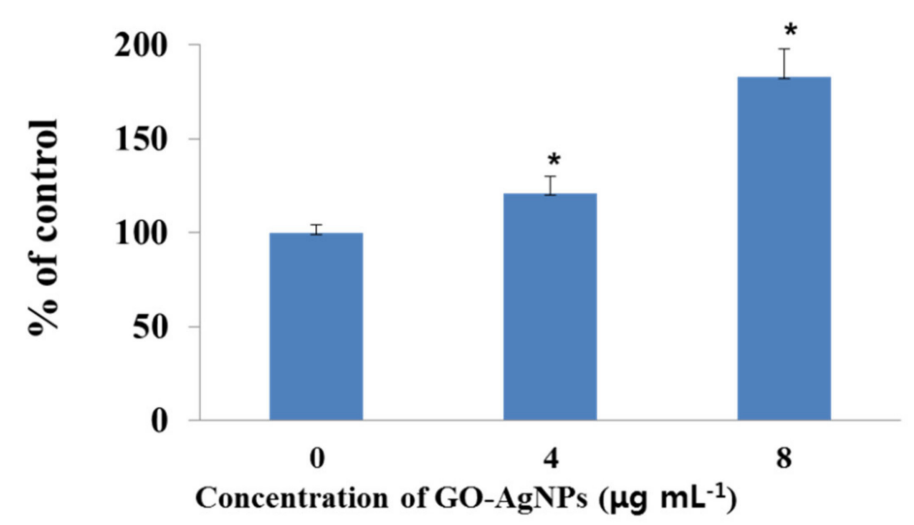

Figure 8. Measurement of lactate dehydrogenase ( $\mathrm{LDH})$ activity in GO-AgNP-treated cells. Caprine fetal fibroblast cells (CFFCs) were treated with 0,4 , and $8 \mu \mathrm{g} / \mathrm{mL}$ of GO-AgNPs for $24 \mathrm{~h}$. The percentage of $\mathrm{LDH}$ activity relative to the control group $(0 \mu \mathrm{g} / \mathrm{mL})$ was determined. Values are presented as the mean $\pm \mathrm{SD}$ of five independent experiments $\left({ }^{*} p<0.05\right)$.

\subsection{Effects of GO-AgNPs on the Caspase-3 Activity}

To confirm whether caspase- 3 is involved in the apoptosis of CFFCs treated with different concentrations of GO-AgNPs ( 4 and $8 \mu \mathrm{g} / \mathrm{mL}$ ), caspase-3 activity was measured by a caspase- 3 kit. The activity of caspase- 3 in the 4 and $8 \mu \mathrm{g} / \mathrm{mL}$ groups was significantly $(p<0.05)$ higher after treatment than that in the control group (Figure 9).

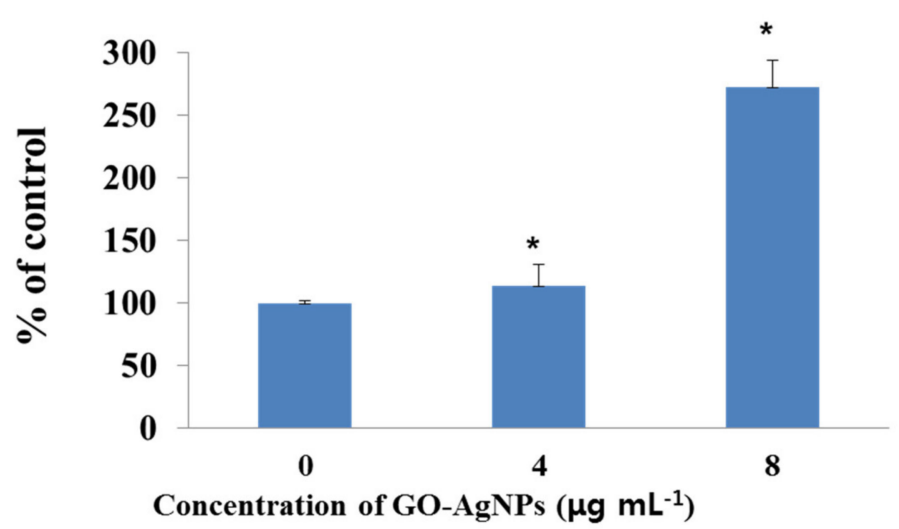

Figure 9. Measurement of caspase-3 activity in GO-AgNP-treated cells. Caprine fetal fibroblast cells (CFFCs) were treated with 0,4 , and $8 \mu \mathrm{g} / \mathrm{mL}$ of GO-AgNPs for $24 \mathrm{~h}$. The percentage of caspase3 activity relative to the control group $(0 \mu \mathrm{g} / \mathrm{mL})$ was determined. Values are presented as the mean $\pm \mathrm{SD}$ of four independent experiments $(* p<0.05)$.

\subsection{Effects of GO-AgNPs on Gene Expression}

To elucidate the possible molecular mechanisms underlying the negative effect of GO-AgNPs, the mRNA levels of pro- and anti-apoptotic genes as well as cell-death- and survival-related genes, including caspase-3, BAX, Smac, Hsp 70 , and BCL2, were measured in CFFCs treated with GO-AgNPs $(0,4$, and $8 \mu \mathrm{g} / \mathrm{mL})$ for $24 \mathrm{~h}$. The results showed that the level of caspase-3, BAX, Smac, and Hsp70 were significantly $(p<0.05)$ upregulated in GO-AgNP-treated cells compared to control cells (Figure 10). The level of the anti-apoptosis gene BCL2 was significantly $(p<0.05)$ downregulated in GO-AgNP-treated cells compared to control cells (Figure 10). 

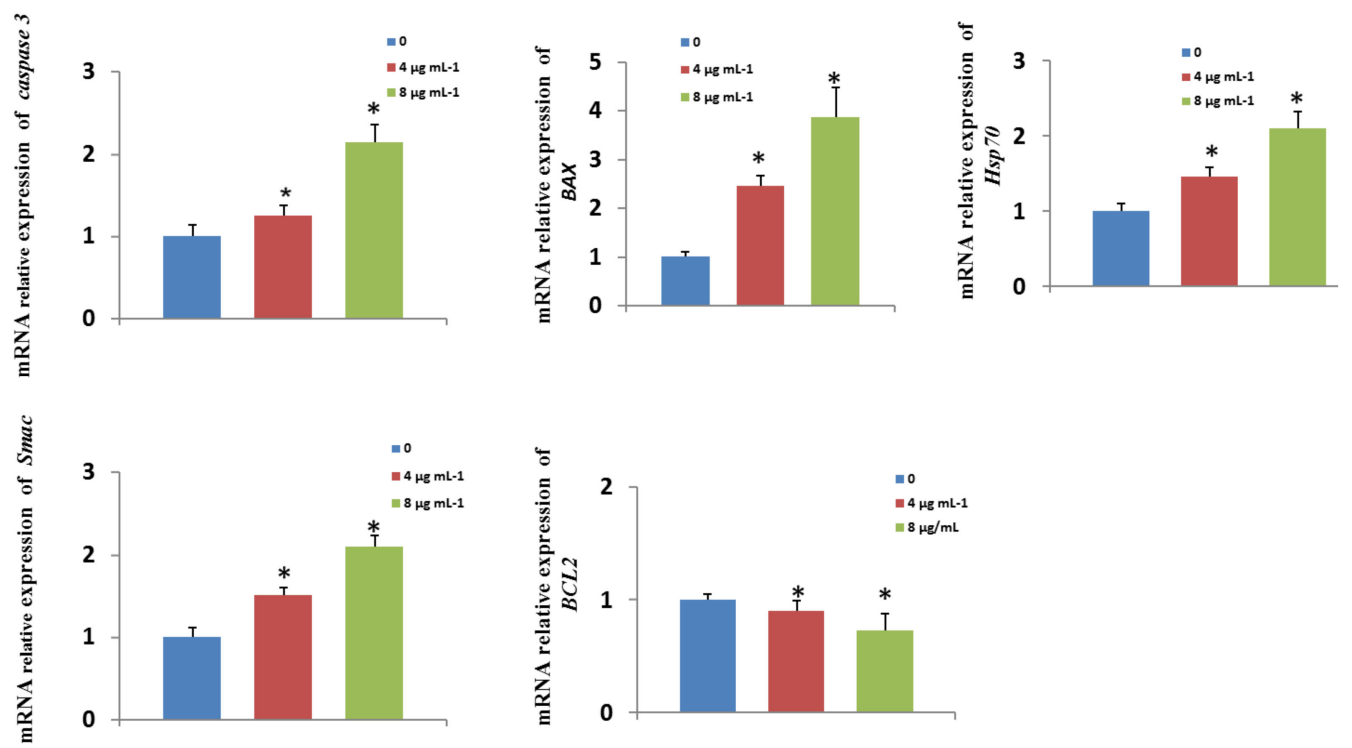

Figure 10. Effects of GO-AgNPs on apoptotic gene expression levels. Caprine fetal fibroblast cells (CFFCs) were treated with 0,4 , and $8 \mu \mathrm{g} / \mathrm{mL}$ of GO-AgNPs for $24 \mathrm{~h}$. Relative mRNA levels of genes related to apoptosis were determined. Values are presented as the mean $\pm \mathrm{SD}$ of four independent experiments $\left({ }^{*} p<0.05\right)$.

\subsection{Effects of GO-AgNPs on Global DNA Methylation}

Global DNA methylation levels decreased in CFFCs exposed to GO-AgNPs (4 and $8 \mu \mathrm{g} / \mathrm{mL}$ ) compared to untreated CFFCs. The mean values of the 4 and $8 \mu \mathrm{g} / \mathrm{mL}$ GO-AgNPtreated CFFCs decreased to $62 \%$ and $10 \%(p<0.05)$ of control cells, respectively (Figure 11A). As shown in Figure 11B, the mRNA expression levels of Dnmt $3 A$ significantly increased after exposure to GO-AgNPs $(p<0.05, p<0.01)$. However, there was no significant difference in the expression of Dnmt1 and Dnmt3B between GO-AgNP-treated groups and controls.

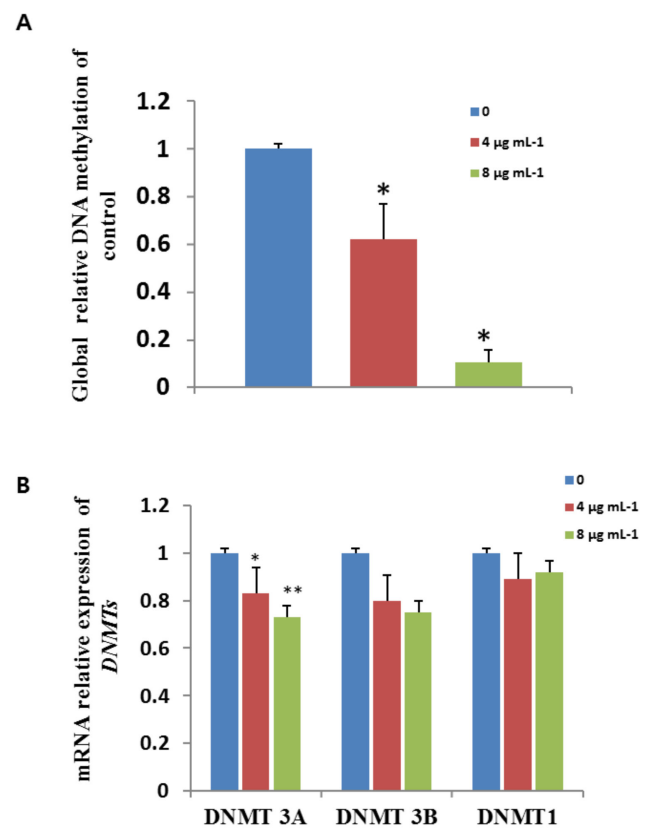

Figure 11. Effects of GO-AgNPs on global DNA methylation and gene expression levels. Caprine fetal fibroblast cells (CFFCs) were treated with 0,4 , and $8 \mu \mathrm{g} / \mathrm{mL}$ of GO-AgNPs for $24 \mathrm{~h}$. Relative global DNA methylation $(\mathbf{A})$ and mRNA levels of DNMTs $(\mathbf{B})$ were determined. Values are presented as the mean $\pm \mathrm{SD}$ of four independent experiments $\left({ }^{*} p<0.05 ;{ }^{* *} p<0.01\right)$. 


\section{Discussion}

Graphene-based nanomaterials have enormous applications in the field of nanomedicine due to their excellent biocompatibility and physicochemical properties [30]. As efficient support materials, graphene sheets can disperse and stabilize silver nanoparticles by preventing their agglomeration, which opens a way for the development of hybrid nanomaterials using both graphene and silver composites. Consequently, graphene-and-AgNP-based hybrid nanocomposites have been widely produced to evaluate their antibacterial and anticancer activity [31]. However, AgNPs can easily enter cells, thus affecting the physiology of organisms, which may show potential toxicity to both human and animal health or ecosystems [11]. Therefore, the adverse effects of GO-AgNP nanocomposites have been considered a major limitation for their broad applications. Numerous studies have proved the toxicological effects of GO-AgNP nanocomposites on normal animal and human cells [20,31,32]. However, the toxic effects of GO-AgNPs on the developing fetus (cells originating from the fetus) of livestock species have not been explored yet. In the present study, a GO-AgNP nanocomposite was synthesized using quercetin, and its surface and structural morphology as well as the uniform distribution of AgNPs on the GO sheets was confirmed using TEM. After that, the potential toxicity level of the synthesized GO-AgNPs on CFFCs was explored.

It has been reported that animals and human are frequently exposed to AgNPs via the routes of inhalation, dermal contact, and oral ingestion [11]. As an in vitro model, cell lines are frequently used for testing the toxic effects of different nanomaterials. For example, several studies have demonstrated that AgNPs induce toxicity via oxidative stress and apoptosis in mouse and rat cell lines [33,34]. AgNPs with a smaller particle size can easily enter and get distributed throughout cytoplasmic organelles [35]. However, smaller AgNPs $(6 \mathrm{~nm})$ are reported to be non-toxic to the mouse fibroblast line and the human keratinocyte cell line [36]. Similar results were reported that $5 \mu \mathrm{g} / \mathrm{mL}$ of rGO-Ag nanocomposite did not induce cytotoxicity in human normal cells (CHANG cells) but could slightly induce a toxic effect on HepG2 cells [32], which may ascribe the differences in toxicity mechanisms to the particular cell type [37]. The present data showed that $20 \mathrm{~nm}$ GO-AgNPs reduced cell growth and viability and induced morphological changes in a concentration-dependent manner. In our previous study, GO-AgNPs significantly decreased the human ovarian cancer cell viability with an IC50 of $5 \mu \mathrm{g} / \mathrm{mL}$ [26], which is lower than that in the present study, suggesting that CFFCs are less sensitive to GO-AgNPs than human cancer or mouse cells. AgNPs with different sizes and surface coatings or without coatings are likely to contribute to these different results. Lopes et al. [38] reported that coated AgNPs have a better dispersion ability and are exposed to cells in a better way than non-coated AgNPs. In addition, the toxicity level varies among the type and origin of the cell lines. For example, compared to L02 cells, HepG2 cells are more sensitive to AgNPs at the exposure level of 20-160 $\mu \mathrm{g} / \mathrm{mL}$ [39].

One of the main mechanisms of toxicity induced by nanomaterials is that it causes oxidative stress through the generation of ROS and causes damage to cellular components, including DNA damage, abnormal activation of transcription factors, depletion of anti-oxidant molecules, binding and disabling of proteins, and damage to the cell membrane [11]. Oxidative stress inducing ROS is one of the proposed toxicological mechanisms of various nanomaterials such as $\mathrm{Ag}$ or Ag-graphene nanocomposites and can cause mitochondrial damage and initiation of lipid peroxidation [26,28,40]. Cytotoxicity of AgNPs is associated with increased production of ROS, which plays an important role in apoptosis induced by AgNPs [41]. Compared to pristine AgNPs, GO-AgNPs significantly induce the generation of ROS in the macrophages in a dose-dependent manner [42]. Especially, the generation of ROS and its association with oxidative stress in cells have been reported as critical indicators of graphene-based-nanomaterial-mediated toxicity, which causes DNA damage and reduced cell viability. A previous study investigated graphene-basednanomaterial-mediated toxicity in biological systems as well as its response in various molecular pathways such as activating base excision repair and PI3K pathways in zebrafish 
larvae [43]. In the current study, GO-AgNPs treatment enhanced the generation of ROS by 1.4- and 1.8-fold in CFFCs treated with 4 and $8 \mu \mathrm{g} / \mathrm{mL}$ of GO-AgNPs for $24 \mathrm{~h}$, respectively. Our results are consistent with previous reports on various cancer cell lines with graphene and graphene-related materials $[16,26]$. The upregulated ROS level in CFFCs alters mitochondrial functions and plays a key role in apoptosis induction, which was proved by the data of the annexin V/PI double-labeling assay and increasing levels of caspase-3. Present data suggest that the possible mechanisms of GO-AgNP-mediated toxicity in CFFCs include the stimulation of oxidative stress, which is responsible for upregulation of pro-apoptotic genes as well as downregulation of anti-apoptotic genes in CFFCs [16].

The increased levels of MDA and LDH are generally considered to imply cell injury. One of the adverse effects of oxidative stress is the lipid peroxidation of cell membranes. Many types of cells treated with AgNPs and GO have shown significantly increased levels of MDA, which is one of the final products of polyunsaturated fatty acid peroxidation in the cells $[2,16,43-45]$. Assessing the release of intracellular LDH in a cell, which results from the breakdown of and alteration in the permeability of the plasma membrane, is one of the markers for estimating cytotoxicity [16,40]. For instance, rGO-Ag increases LDH leakage in human cancer cells, thus resulting in cell death $[16,26,46]$. In the present study, the LDH level in the $4 \mu \mathrm{g} / \mathrm{mL}$ group was slightly higher than the control group, which is the same as the cell viability and apoptotic cell data. It means that although a low concentration of GO-AgNPs $(4 \mu \mathrm{g} / \mathrm{mL})$ seems to be toxic to cells, it may also result in some change in the cells. The present data indicated that the mechanism of increased levels of MDA and LDH in GO-AgNP-treated CFFCs may be due to ROS formation, which influenced the viability and proliferation of the cells, suggesting the possible cytotoxic effects of GO-AgNPs on CFFCs.

The apoptosis of cells is a highly conserved mechanism, and ROS is an important factor involved in the apoptotic process [47]. ROS induced by nanomaterials could result in nuclear DNA damage as well as leakage of lipids, proteins, and carbohydrates in the cell [34,45]. ROS production and lipid peroxidation induced by GO-AgNPs affect cellular redox homeostasis and decrease anti-oxidant levels [46]. It is well known that SOD plays an important role in anti-oxidant defense against oxidative stress in cells that can combat the accumulation of ROS and reduce oxidative injury. A decrease in SOD activity is an indicator of impairment of protective mechanisms and significantly contributes to cell damage [48]. It has been reported that AgNPs directly interact with SOD and CAT and altered the expression and activity of anti-oxidant enzymes (CAT, SOD, and GPX) [48]. The present data showed that the level of SOD significantly decreased in GO-AgNP-treated CFFCs. It suggests that GO-AgNPs decrease the levels of anti-oxidant molecules in the cells, which might be the reason for cytotoxicity.

Similarly, apoptotic and anti-apoptotic genes play an important role in cell survival and death. Several studies have reported oxidative stress and DNA damage as the mechanism for GO-AgNP-induced cytotoxicity and apoptosis of cancer cells [20]. A similar study reported that GO-AgNPs can cause oxidative damage and leakage of LDH and enhance the expression of apoptotic genes $p 53$, caspase-3, caspase-9, Bax, and c-myc, thus leading to mitochondrial dysfunction and triggering apoptosis [29], and all apoptotic pathways appear to terminate in the activation of the caspase family of proteases [49]. Moreover, oxidative stress induced by GO-AgNPs is reported to increase the total expression of Bax in a dose-dependent manner and downregulate the expression of the anti-apoptotic gene $B C L-2$ [46]. Heat shock protein 70 (HSP70) allows cells to adapt to gradual environment changes and is considered to play a crucial role in environmental stress tolerance [50]. The present data also showed that GO-AgNPs upregulate the expression of HSP70 and pro-apoptotic genes such as caspase-3, Bax, and Smac and downregulate anti-apoptotic genes such as $\mathrm{Bcl}-2$. Similarly, rGO-Ag was reported to cause dynamic balance troubles in the level of $B c l-x l$ and $B c l-2$, and downregulation of $c-m y c$ triggers apoptosis along with $p 53$ [29], which may induce apoptosis of CFFCs. 
It has been reported that nanomaterials induce epigenetic changes, including DNA methylation, histone modifications, and noncoding RNA-mediated regulation of gene expression [50]. Nanoparticle-mediated global DNA hypomethylation or hypermethylation can be corroborated with increased generation of ROS [14], which is now known to cause many human diseases, including cancer [51]. Nanomaterial-induced epigenetic changes are also shown to be cell type, time, and dose dependent. For example, ZnO-NPs induced increasing levels of ROS and significantly resulted in global reduction in 5-mC [52], while AgNP exposure to pregnant mice via intravenous infusion significantly altered the methylation levels of differentially methylated regions of Zac1 and disrupted the imprinted gene expression [53]. However, exposure of AgNPs via the abdominal subcutaneous route had detrimental effects on spermatogenesis and the quality of sperm in neonatal mice [54]. The current research showed that GO-AgNP treatment causes a significant reduction in global 5-mC in CFFCs, which was further proved by the decreased expression of DNMT3A. After recovering from the treatment of AgNPs, HT22 mouse hippocampal neuronal cells showed increased levels of 5-mC, DNMT3A, and DNMT3B [54]. The different expressions of DNMT3A and DNMT3B in our study may be explained as Dnmt3a or Dnmt3b selectively recognizing heterochromatin [55]. Therefore, the global DNA hypomethylation in the GO-AgNP-treated CFFCs might be the result of aberrant oxidative stress.

Author Contributions: Y.-G.Y. designed the study, analyzed the data, drafted the manuscript, and performed experiments for nanoparticles and toxicity of cells. H.-Q.C. rand J.-L.W. performed cell culture. A.M. performed statistical analysis of the data and aided in data analysis. A.M.M.T.R. and L.C. reviewed and revised the manuscript, as well as supported the writing of the manuscript. L.L. and C.Q. developed and performed qPCR analysis. All authors have read and agreed to the published version of the manuscript.

Funding: This research was supported by the Priority Academic Program Development of Jiangsu Higher Education Institutions (PAPD), Yangzhou City and Yangzhou University Corporation (YZ2020185), the Open Project Program of Jiangsu Key Laboratory of Zoonosis (no. R1807), and the Joint International Research Laboratory of Agriculture and Agri-Product Safety, the Ministry of Education of China, Yangzhou University (JRK2018-11/JILAR-KF202015).

Institutional Review Board Statement: The study was approved by the Animal Ethics Committee of Yangzhou University. Goats were handled in accordance with the Animal Ethics Procedures and Guidelines of the People's Republic of China. All procedures collecting $70 \mathrm{~d}$ caprine fetuses were approved by the Animal Ethics Committee of Yangzhou University (no. 2018.1109).

Informed Consent Statement: Not applicable.

Data Availability Statement: Data available in a publicly accessible repository.

Conflicts of Interest: The authors declare no conflict of interest.

\section{References}

1. Pinho, A.R.; Martins, F.; Costa, M.; Senos, A.; Silva, O.; Pereira, M.L.; Rebelo, S. In vitro cytotoxicity effects of zinc oxide nanoparticles on spermatogonia cells. Cells 2020, 9, 1081. [CrossRef] [PubMed]

2. Gurunathan, S.; Kim, J.H. Graphene oxide-silver nanoparticles nanocomposite stimulates differentiation in human neuroblastoma cancer cells (SH-SY5Y). Int. J. Mol. Sci. 2017, 18, 2549. [CrossRef] [PubMed]

3. Gies, V.; Zou, S. Systematic toxicity investigation of graphene oxide: Evaluation of assay selection, cell type, exposure period and flake size. Toxicol. Res. 2018, 7, 93-101. [CrossRef] [PubMed]

4. Gurunathan, S.; Han, J.W.; Eppakayala, V.; Dayem, A.A.; Kwon, D.N.; Kim, J.H. Biocompatibility effects of biologically synthesized graphene in primary mouse embryonic fibroblast cells. Nanoscale. Res. Lett. 2013, 8, 393. [CrossRef]

5. Thapa, R.K.; Kim, J.H.; Jeong, J.H.; Shin, B.S.; Choi, H.G.; Yong, C.S.; Kim, J.O. Silver nanoparticle-embedded graphene oxide-methotrexate for targeted cancer treatment. Colloids. Surf. B. Biointerfaces 2017, 153, 95-103. [CrossRef] [PubMed]

6. Syama, S.; Paul, W.; Sabareeswaran, A.; Mohanan, P.V. Raman spectroscopy for the detection of organ distribution and clearance of PEGylated reduced graphene oxide and biological consequences. Biomaterials 2017, 131, 121-130. [CrossRef] [PubMed]

7. Nurunnabi, M.; Khatun, Z.; Huh, K.M.; Park, S.Y.; Lee, D.Y.; Cho, K.J.; Lee, Y.K. In vivo biodistribution and toxicology of carboxylated graphene quantum dots. ACS. Nano 2013, 7, 6858-6867. [CrossRef]

8. Ivask, A.; Voelcker, N.H.; Seabrook, S.A.; Hor, M.; Kirby, J.K.; Fenech, M.; Davis, T.P.; Ke, P.C. DNA melting and genotoxicity induced by silver nanoparticles and graphene. Chem. Res. Toxicol. 2015, 28, 1023-1035. [CrossRef] [PubMed] 
9. Hyun, J.S.; Lee, B.S.; Ryu, H.Y.; Sung, J.H.; Chung, K.H.; Yu, I.J. Effects of repeated silver nanoparticles exposure on the histological structure and mucins of nasal respiratory mucosa in rats. Toxicol. Lett. 2008, 182, 24-28. [CrossRef] [PubMed]

10. Rosas-Hernandez, H.; Jimenez-Badillo, S.; Martinez-Cuevas, P.P.; Gracia-Espino, E.; Terrones, H.; Terrones, M.; Hussain, S.M.; Ali, S.F.; González, C. Effects of 45-nm silver nanoparticles on coronary endothelial cells and isolated rat aortic rings. Toxicol. Lett. 2009, 191, 305-313. [CrossRef] [PubMed]

11. Rezvani, E.; Rafferty, A.; McGuinness, C.; Kennedy, J. Adverse effects of nanosilver on human health and the environment. Acta. Biomater. 2019, 94, 145-159. [CrossRef]

12. Jia, P.P.; Sun, T.; Junaid, M.; Yang, L.; Ma, Y.B.; Cui, Z.S.; Wei, D.P.; Shi, H.F.; Pei, D.S. Nanotoxicity of different sizes of graphene (G) and graphene oxide (GO) in vitro and in vivo. Environ. Pollut. 2019, 247, 595-606. [CrossRef] [PubMed]

13. Seabra, A.B.; Paula, A.J.; de Lima, R.; Alves, O.L.; Durán, N. Nanotoxicity of graphene and graphene oxide. Chem. Res. Toxicol. 2014, 27, 159-168. [CrossRef] [PubMed]

14. Pogribna, M.; Hammons, G. Epigenetic Effects of nanomaterials and nanoparticles. J. Nanobiotechnol. 2021, 19, 2. [CrossRef]

15. Uzair, B.; Liaqat, A.; Iqbal, H.; Menaa, B.; Razzaq, A.; Thiripuranathar, G.; Rana, N.F.; Menaa, F. Green and cost-effective synthesis of metallic nanoparticles by algae: Safe methods for translational medicine. Bioengineering 2020, 7, 129. [CrossRef]

16. Gurunathan, S.; Han, J.W.; Park, J.H.; Kim, E.; Choi, Y.J.; Kwon, D.N.; Kim, J.H. Reduced graphene oxide-silver nanoparticle nanocomposite: A potential anticancer nanotherapy. Int. J. Nanomed. 2015, 10, 6257-6276. [CrossRef]

17. Gurunathan, S.; Hyun Park, J.; Choi, Y.J.; Woong Han, J.; Kim, J.H. Synthesis of graphene oxide-silver nanoparticle nanocomposites: An efficient novel antibacterial agent. Curr. Nanosci. 2016, 12, 762-773. [CrossRef]

18. Cobos, M.; De-La-Pinta, I.; Quindós, G.; Fernández, M.J.; Fernández, M.D. Graphene Oxide-Silver Nanoparticle Nanohybrids: Synthesis, Characterization, and Antimicrobial Properties. Nanomaterials 2020, 10, 376. [CrossRef] [PubMed]

19. Akter, M.; Sikder, M.T.; Rahman, M.M.; Ullah, A.K.M.A.; Hossain, K.F.B.; Banik, S.; Hosokawa, T.; Saito, T.; Ku-rasaki, M. A systematic review on silver nanoparticles-induced cytotoxicity: Physicochemical properties and perspectives. J. Adv. Res. 2017, 9, 1-16. [CrossRef]

20. Courtois, P.; Rorat, A.; Lemiere, S.; Guyoneaud, R.; Attard, E.; Levard, C.; Vandenbulcke, F. Ecotoxicology of silver nanoparticles and their derivatives introduced in soil with or without sewage sludge: A review of effects on microorganisms, plants and animals. Environ. Pollut. 2019, 253, 578-598. [CrossRef] [PubMed]

21. Brami, C.; Glover, A.R.; Butt, K.R.; Lowe, C.N. Effects of silver nanoparticles on survival, biomass change and avoidance behaviour of the endogeic earthworm Allolobophora chlorotica. Ecotoxicol. Environ. Saf. 2017, 141, 64-69. [CrossRef] [PubMed]

22. Ong, C.; Lee, Q.Y.; Cai, Y.; Liu, X.; Ding, J.; Yung, L.Y.; Bay, B.H.; Baeg, G.H. Silver nanoparticles disrupt germline stem cell maintenance in the Drosophila testis. Sci. Rep. 2016, 6, 1-10. [CrossRef]

23. Vadalasetty, K.P.; Lauridsen, C.; Engberg, R.M.; Vadalasetty, R.; Kutwin, M.; Chwalibog, A.; Sawosz, E. Influence of silver nanoparticles on growth and health of broiler chickens after infection with campylobacter jejuni. BMC Vet. Res. $2018,14,1$. [CrossRef] [PubMed]

24. Yuan, Y.G.; Peng, Q.L.; Gurunathan, S. Effects of Silver Nanoparticles on Multiple Drug-Resistant Strains of Staphylococcus aureus and Pseudomonas aeruginosa from Mastitis-Infected Goats: An Alternative Approach for Antimicrobial Therapy. Int. J. Mol. Sci. 2017, 18, 569. [CrossRef]

25. Zhang, X.F.; Park, J.H.; Choi, Y.J.; Kang, M.H.; Gurunathan, S.; Kim, J.H. Silver nanoparticles cause complica-tions in pregnant mice. Int. J. Nanomed. 2015, 10, 7057-7071.

26. Yuan, Y.G.; Wang, Y.H.; Xing, H.H.; Gurunathan, S. Quercetin-mediated synthesis of graphene oxide-silver nanoparticle nanocomposites: A suitable alternative nanotherapy for neuroblastoma. Int. J. Nanomed. 2017, 12, 5819-5839. [CrossRef]

27. Yuan, Y.G.; Song, S.Z.; Zhu, M.M.; He, Z.Y.; Lu, R.; Zhang, T.; Mi, F.; Wang, J.Y.; Cheng, Y. Human lactoferrin efficiently targeted into caprine beta-lactoglobulin locus with transcription activator-like effector nucleases. Asian-Australas. J. Anim. Sci. 2017, 30, $1175-1182$.

28. Yuan, Y.G.; Zhang, S.; Hwang, J.Y.; Kong, I.K. Silver nanoparticles potentiates cytotoxicity and apoptotic potential of camptothecin in human cervical cancer cells. Oxid. Med. Cell. Longev. 2018, 2018, 6121328. [CrossRef] [PubMed]

29. Choi, Y.J.; Gurunathan, S.; Kim, J.H. Graphene oxide-silver nanocomposite enhances cytotoxic and apoptotic potential of salinomycin in human ovarian cancer stem cells (OvCSCs): A novel approach for cancer therapy. Int. J. Mol. Sci. 2018, 19, 710. [CrossRef]

30. Gurunathan, S.; Kim, J.H. Synthesis, toxicity, biocompatibility, and biomedical applications of graphene and graphene-related materials. Int. J. Nanomed. 2016, 11, 1927-1945. [CrossRef]

31. He, K.; Zeng, Z.; Chen, A.; Zeng, G.; Xiao, R.; Xu, P.; Huang, Z.; Shi, J.; Hu, L.; Chen, G. Advancement of ag-graphene based nanocomposites: An overview of synthesis and its applications. Small 2018, 14, e1800871. [CrossRef] [PubMed]

32. Ali, D.; Alarifi, S.; Alkahtani, S.; Almeer, R.S. Silver-doped graphene oxide nanocomposite triggers cytotoxicity and apoptosis in human hepatic normal and carcinoma cells. Int. J. Nanomed. 2018, 13, 5685-5699. [CrossRef] [PubMed]

33. Zhang, X.F.; Choi, Y.J.; Han, J.W.; Park, J.H.; Gurunathan, S.; Kim, J.H. Differential nanoreprotoxicity of silver nanoparticles in male somatic cells and spermatogonial stem cells. Int. J. Nanomed. 2015, 10, 1335-1357.

34. Xu, F.; Piett, C.; Farkas, S.; Qazzaz, M.; Syed, N.I. Silver nanoparticles (AgNPs) cause degeneration of cytoskeleton and disrupt synaptic machinery of cultured cortical neurons. Mol. Brain. 2013, 6, 29. [CrossRef] [PubMed]

35. Hondroulis, E.; Liu, C.; Li, C.Z. Whole cell based electrical impedance sensing approach for a rapid nanotoxicity assay. Nanotechnology 2010, 21, 315103. [CrossRef] 
36. Abdel-Mohsen, A.M.; Abdel-Rahman, R.M.; Fouda, M.M.; Vojtova, L.; Uhrova, L.; Hassan, A.F.; Al-Deyab, S.S.; El-Shamy, I.E.; Jancar, J. Preparation, characterization and cytotoxicity of schizophyllan/silver nanoparticle composite. Carbohydr. Polym. 2014, 102, 238-245. [CrossRef]

37. Sahu, S.C.; Zheng, J.W.; Graham, L.; Chen, L.; Ihrie, J.; Yourick, J.J.; Sprando, R.L. Comparative cytotoxicity of nanosilver in human liver HepG2 and colon Caco2 cells in culture. J. Appl. Toxicol. 2014, 34, 1155-1166. [CrossRef]

38. Lopes, I.M.D.; de Oliveira, I.M.; Bargi-Souza, P.; Cavallin, M.D.; Kolc, C.S.M.; Khalil, N.M.; Quináia, S.P.; Romano, M.A.; Romano, R.M. Effects of silver nanoparticle exposure to the testicular antioxidant system during the prepubertal rat stage. Chem. Res. Toxicol. 2019, 32, 986-994. [CrossRef] [PubMed]

39. Xue, Y.; Wang, J.; Huang, Y.; Gao, X.; Zhang, T.; Tang, M.; Tang, M. Comparative cytotoxicity and apoptotic pathways induced by nanosilver in human liver HepG2 and L02 cells. Hum. Exp. Toxicol. 2018, 37, 1293-1309. [CrossRef] [PubMed]

40. Yuan, Y.G.; Peng, Q.L.; Gurunathan, S. Silver nanoparticles enhance the apoptotic potential of gemcitabine in human ovarian cancer cells: Combination therapy for effective cancer treatment. Int. J. Nanomed. 2017, 12, 6487-6502. [CrossRef]

41. Lee, Y.H.; Cheng, F.Y.; Chiu, H.W.; Tsai, J.C.; Fang, C.Y.; Chen, C.W.; Wang, Y.J. Cytotoxicity, oxidative stress, apoptosis and the autophagic effects of silver nanoparticles in mouse embryonic fibroblasts. Biomaterials 2014, 35, 4706-4715. [CrossRef] [PubMed]

42. De Luna, L.A.; de Moraes, A.C.; Consonni, S.R.; Pereira, C.D.; Cadore, S.; Giorgio, S.; Alves, O.L. Comparative in vitro toxicity of a graphene oxide-silver nanocomposite and the pristine counterparts toward macrophages. J. Nanobiotechnol. $2016,14,12$. [CrossRef]

43. El-Sonbaty, S.M. Fungus-mediated synthesis of silver nanoparticles and evaluation of antitumor activity. Cancer Nanotechnol. 2013, 4, 73-79. [CrossRef] [PubMed]

44. Liao, K.H.; Lin, Y.S.; Macosko, C.W.; Haynes, C.L. Cytotoxicity of graphene oxide and graphene in human erythrocytes and skin fibroblasts. ACS Appl. Mater. Interfaces 2011, 3, 2607-2615. [CrossRef]

45. Yuan, Y.G.; Gurunathan, S. Combination of graphene oxide-silver nanoparticle nanocomposites and cisplatin enhances apoptosis and autophagy in human cervical cancer cells. Int. J. Nanomed. 2017, 12, 6537-6558. [CrossRef] [PubMed]

46. Zhang, X.F.; Huang, F.H.; Zhang, G.L.; Bai, D.P.; Massimo, D.F.; Huang, Y.F.; Gurunathan, S. Novel biomolecule lycopene-reduced graphene oxide-silver nanoparticle enhances apoptotic potential of trichostatin A in human ovarian cancer cells (SKOV3). Int. J. Nanomed. 2017, 12, 7551-7575. [CrossRef] [PubMed]

47. Yuan, Y.G.; Xu, L.; Zhang, S.; Mesalam, A.; Lee, K.L.; Liu, H.; Joo, M.D.; Idrees, M.; Kong, I.K. Polydatin and I-CBP112 protects early bovine embryo against nicotinamide-induced mitochondrial dysfunction. Theriogenology 2019, 134, 1-10. [CrossRef]

48. Fang, W.; Chi, Z.; Li, W.; Zhang, X.; Zhang, Q. Comparative study on the toxic mechanisms of medical nanosilver and silver ions on the antioxidant system of erythrocytes: From the aspects of antioxidant enzyme activities and molecular interaction mechanisms. J. Nanobiotechnol. 2019, 17, 66. [CrossRef] [PubMed]

49. Mesalam, A.; Khan, I.; Lee, K.L.; Song, S.H.; Chowdhury, M.M.R.; Uddin, Z.; Park, K.H.; Kong, I.K. 2-methoxystypandrone improves in vitro-produced bovine embryo quality through inhibition of IKBKB. Theriogenology 2017, 99, 10-20. [CrossRef]

50. Feder, M.E.; Hofmann, G.E. Heat-shock proteins, molecular chaperones, and the stress response: Evolutionary and ecological physiology. Annu. Rev. Physiol. 1999, 6, 243-282. [CrossRef]

51. Zhang, W.; Liu, S.; Han, D.; He, Z. Engineered nanoparticle-induced epigenetic changes: An important consideration in nanomedicine. Acta Biomater. 2020, 117, 93-107. [CrossRef] [PubMed]

52. Choudhury, S.R.; Ordaz, J.; Lo, C.L.; Damayanti, N.P.; Zhou, F.; Irudayaraj, J. From the Cover: Zinc oxide Nanoparticles-Induced Reactive Oxygen Species Promotes Multimodal Cyto- and Epigenetic Toxicity. Toxicol. Sci. 2017, 156, 261-274. [PubMed]

53. Zhang, X.F.; Gurunathan, S.; Kim, J.H. Effects of silver nanoparticles on neonatal testis development in mice. Int. J. Nanomed. 2015, 10, 6243-6256.

54. Mytych, J.; Zebrowski, J.; Lewinska, A.; Wnuk, M. Prolonged Effects of Silver Nanoparticles on p53/p21 Pathway-Mediated Proliferation, DNA Damage Response, and Methylation Parameters in HT22 Hippocampal Neuronal Cells. Mol. Neurobiol. 2017, 54, 1285-1300. [CrossRef] [PubMed]

55. Tajima, S.; Suetake, I.; Takeshita, K.; Nakagawa, A.; Kimura, H. Domain Structure of the Dnmt1, Dnmt3a, and Dnmt3b DNA Methyltransferases. Adv. Exp. Med. Biol. 2016, 945, 63-86. [PubMed] 